\title{
Badania procesu żelowania zaczynów cementowych przeznaczonych do uszczelniania otworów przewiercających płytkie poziomy gazonośne
}

\author{
Research on the gelling process of cement slurries for sealing boreholes drilling through \\ shallow gas-bearing levels
}

\author{
Marcin Rzepka, Miłosz Kędzierski \\ Instytut Nafty i Gazu - Państwowy Instytut Badawczy
}

\begin{abstract}
STRESZCZENIE: Niniejszy artykuł przedstawia zagadnienia z zakresu technologii zaczynów uszczelniających dotyczące tzw. procesów żelowania (tzn. narastania statycznej wytrzymałości strukturalnej zaczynów cementowych). Na podstawie badań prowadzonych na świecie można stwierdzić, że tempo żelowania zaczynu cementowego odgrywa istotną rolę w procesie przeciwdziałania ewentualnym ekshalacjom gazowym z przestrzeni pierścieniowej. Po wtłoczeniu zaczynu do otworu (zwłaszcza w strefach, w których występują płytko zalegające horyzonty gazowe) może dojść do tzw. migracji (ekshalacji) medium złożowego (tj. niekontrolowanego wypływu np. gazu z przestrzeni pierścieniowej otworu wiertniczego). Do najważniejszych przyczyn powstawania zjawiska migracji gazu z płytkich horyzontów po zabiegu cementowania rur zalicza się niezdolność do utrzymania określonego nadciśnienia przez kolumnę wiążącego zaczynu cementowego oraz zbyt długie wiązanie zaczynu cementowego po zatłoczeniu go do otworu. Zaczyn cementowy po wytłoczeniu poza rury okładzinowe, będący początkowo w stanie płynnym, działa jako ciecz, wywołując określone ciśnienie hydrostatyczne na złoże, np. gazowe. Jednakże po pewnym czasie rozpoczyna się okres budowy statycznej wytrzymałości strukturalnej (SGS, ang. static gel strength), aż do momentu związania cementu. Proces budowy SGS, czyli tzw. żelowania zaczynu cementowego, powoduje ograniczenie zdolności do transmisji (przekazywania) ciśnienia hydrostatycznego na złoże. W Instytucie Nafty i Gazu - Państwowym Instytucie Badawczym przetestowano szereg receptur zaczynów cementowych charakteryzujących się różnym czasem żelowania i wiązania. Zaczyny sporządzane były na bazie m.in.: trzech rodzajów lateksów (o symbolach L1, L2, L3), dwóch rodzajów szkła wodnego (o symbolach $\mathrm{S} 1, \mathrm{~S} 2$ ), krzemionki bezpostaciowej (o symbolu $\mathrm{CB}$ ), nanokomponentów na bazie n-SiO ${ }_{2}$ i n- $\mathrm{Al}_{2} \mathrm{O}_{3}$ (o symbolach NS i NA) oraz polimeru wielkocząsteczkowego (o symbolu GS). Do testowanych zaczynów stosowano przyspieszacz wiązania w różnych ilościach. Łącznie wykonano badania dla 18 receptur cementowych, co pozwoliło na wytypowanie optymalnych składów zaczynów o krótkich czasach żelowania i wiązania. Próbki zawierające w odpowiedniej koncentracji jeden z rodzajów lateksu, polimer GS, jak i te zawierające n- $\mathrm{SiO}_{2} \mathrm{i} n-\mathrm{Al}_{2} \mathrm{O}_{3}$ cechowały się bardzo korzystnym przebiegiem krzywej żelowania (narastania statycznej wytrzymałości strukturalnej). Ich czasy przejścia (TT, ang. transition time), odzwierciedlające przebieg żelowania, wynosiły od kilkunastu do kilkudziesięciu minut (co świadczy o ich wysokiej zdolności do zapobiegania migracji gazu z płytkich horyzontów produktywnych). Opracowane w INiG - PIB zaczyny cementowe, z uwagi na ich dobre parametry technologiczne, mogłyby znaleźć zastosowanie w procesie cementowania kolumn rur okładzinowych w otworach wiertniczych, zwłaszcza w przypadkach spodziewanego płytkiego zalegania poziomów gazonośnych.
\end{abstract}

Słowa kluczowe: zaczyn cementowy, czas przejścia, migracja gazu, wiązanie cementu.

ABSTRACT: The article presents issues related to the sealing slurry technology concerning gelling processes (i.e., static built-up of gel strength of cement slurries). Based on research conducted around the world, it can be concluded that the rate of gelling of the cement slurry has an important role in the process of preventing possible gas exhalations from the annular space. After the cement slurry is pumped into the borehole (especially in zones with shallow gas horizons), the so-called migration (exhalation) of the formation medium (i.e. uncontrolled outflow of e.g. gas from the annular space) may occur. The most important caused of gas migration from the shallow horizons after casings cementation are the inability to maintain a certain overpressure by the column of the binding cement slurry and too long binding of the cement slurry after pumping into the borehole. The initially liquid cement slurry, when pumped out of the casing, acts as a liquid, creating a certain hydrostatic pressure on the deposit. e.g. gas. However, after some time, the period of building the static gel strength (SGS) starts until the cement sets. The SGS building process, i.e. gelling of the cement slurry, reduces the ability to transmit hydrostatic pressure to the reservoir. The Oil and Gas Institute - National Research Institute has tested a number of cement slurry formulations characterized by different gelling and bonding times. Slurries were made on the basis of three typed of latex with the symbols L1, L2, L3, two types of

Autor do korespondencji: M. Rzepka, e-mail: marcin.rzepka@inig.pl

Artykuł nadesłano do Redakcji: 21.02.2021 r. Zatwierdzono do druku: 07.04.2021 r. 
water glass with symbols $\mathrm{S} 1, \mathrm{~S} 2$, amorphous silica with the symbol $\mathrm{CB}$, nano-components based on $\mathrm{n}-\mathrm{SiO}_{2}$ and n- $\mathrm{Al}_{2} \mathrm{O}_{3}$ with the symbols NS and NA as well as high-molecular weight polymer with the symbol GS. Different amounts of setting accelerator were used with the tested slurries. Tests were carried out for eighteen cement recipes, which made it possible to select the optimal compositions of slurries with short gelling and setting times. The samples containing one of the types of latex in the appropriate concentration, the GS polymer, as well as those containing $\mathrm{n}-\mathrm{SiO}_{2}$ and $\mathrm{n}-\mathrm{Al}_{2} \mathrm{O}_{3}$, showed a very advantageous course of the gelation plot (static build-up of gel strength). Their TT transition times, reflecting the course of gelation, ranged from several to several tens of minutes (which is a proof of high ability to prevent gas migration from shallow gas accumulations). The cement slurries developed at the Oil and Gas Institute - National Research Institute, due to their good technological parameters, could be used in the process of cementing casing strings.

Key words: cement slurry, transition time, gas migration, cement setting.

\section{Wprowadzenie}

Cementowanie otworów wiertniczych jest zaliczane do najistotniejszych zabiegów wykonywanych w trakcie całego procesu wiercenia otworu. Zasadniczą rolę w tym zabiegu odgrywa zaczyn cementowy, który po zatłoczeniu do otworu stopniowo zaczyna wiązać, przechodząc w kamień cementowy. Proces wiązania zaczynu może trwać od kilku do kilkunastu godzin, w zależności od warunków otworowych oraz jego składu fizykochemicznego. Powstały po związaniu płynnego zaczynu płaszcz cementowy musi być na tyle wytrzymały, aby nie ulec popękaniu w wyniku działania ciśnień panujących w otworze (m.in. ciśnienia złożowego). Ponadto płaszcz cementowy musi być w stanie oprzeć się ciśnieniu hydrostatycznemu powstającemu w czasie wiercenia otworu, być odporny na zmiany temperatury i ciśnienia $\mathrm{w}$ otworze, a także okresowe obciążenia powstające na skutek różnych prac związanych z eksploatacją węglowodorów, a także nie ulegać szybkiej korozji.

Uzyskanie zaczynu cementowego o odpowiedniej wczesnej wytrzymałości mechanicznej jest dla wykonawcy otworu niezwykle istotne, zarówno ze względów technologicznych, jak i ekonomicznych. Po zatłoczeniu zaczynu cementowego do przestrzeni pierścieniowej otworu wiertniczego zaczyna się jego proces hydratacji. Tworzy się stan przejściowy pomiędzy stanem płynnym a fazą stałą, czyli tzw. struktura żelowa. W tym czasie w otworze następuje również redukcja ciśnienia hydrostatycznego. W przypadku zakłócenia równowagi ciśnień w początkowym okresie hydratacji może dojść do wtargnięcia gazu lub cieczy do przestrzeni pierścieniowej, co może stanowić duży problem w perspektywie dalszej eksploatacji odwiertu. Gaz lub ciecz, przemieszczając się ze strefy wyższego ciśnienia do strefy o niższym ciśnieniu, stanowi zagrożenie dla środowiska naturalnego, jak również może powodować spadek wydajności wydobycia (Velayati et al., 2015).

W literaturze światowej i krajowej (Crook i Heathman, 1998; Radecki i Witek, 2000; Scott et al., 2003; Rogers et al., 2004; Velayati et al., 2015; Rzepka i Kędzierski, 2019, 2020) opisano m.in. wpływ statycznej wytrzymałości strukturalnej zaczynu (SGS, ang. static gel strength) na przeciwdziałanie wystąpienia ewentualnego zjawiska migracji gazu. Tempo zmian statycznej wytrzymałości strukturalnej zaczynu decyduje w głównej mierze o zdolności zaczynu do zapobiegania przechodzeniu gazu przez strukturę cementową. Im szybciej SGS narasta, tym mniejsze prawdopodobieństwo powstawania zjawiska migracji gazu. Wraz z wydłużeniem czasu przejścia wzrasta ryzyko wystąpienia migracji gazu lub przepływu płynów przez wiążący płaszcz cementowy w otworze wiertniczym (Mohammadi i Moghadasi, 2007; Dębińska, 2013). Istotną rolę w zabezpieczaniu przed wypływami gazu odgrywa ponadto zapewnienie odpowiednio dobranego do warunków otworowych czasu wiązania zaczynu, tj. czasu, po którym płynny zaczyn cementowy stwardnieje i przejdzie w związany kamień cementowy (Stryczek i Gonet, 2001; ASTM International, 2010).

\section{Żelowanie i hydratacja zaczynu cementowego}

Proces hydratacji i żelowania zaczynu cementowego jest złożonym zjawiskiem przebiegającym w mieszaninie cementu z wodą (Neville, 2000; Kurdowski, 2010, 2014; Ridi, 2010). Podczas wiązania zaczynu cementowego zachodzi szereg reakcji chemicznych, które mają zasadnicze znaczenie dla wytrzymałości mechanicznej powstającego kamienia cementowego. Hydratacja i żelowanie zaczynu cementowego nie mają charakteru liniowego w czasie.

Zasadnicze znaczenie podczas początkowego okresu hydratacji zaczynu odgrywa faza $\mathrm{C}_{3} \mathrm{~S}$, z uwagi na jej większe natężenie w porównaniu do hydratacji fazy $\mathrm{C}_{2} \mathrm{~S}$. Z kolei hydratacja fazy $\mathrm{C}_{2} \mathrm{~S}$ odpowiada $\mathrm{w}$ znacznym stopniu za końcową wytrzymałość kamienia cementowego. Mechanizmy hydratacji obu faz $\left(\mathrm{C}_{3} \mathrm{~S}\right.$ oraz $\left.\mathrm{C}_{2} \mathrm{~S}\right)$ przebiegają $\mathrm{w}$ bardzo podobny sposób. Można w nich wyróżnić okresy:

- przedindukcyjny - trwający do kilku minut, o największym stopniu wydzielania ciepła (najbardziej egzotermiczny). Następuje wówczas gwałtowne uwodnienie cementu natychmiast po kontakcie z wodą. Powstaje początkowa warstwa żelu C-S-H na powierzchni fazy $\mathrm{C}_{3} \mathrm{~S}$;

- indukcji - następuje spadek wydzielania ciepła i powolne wytrącanie żelu C-S-H, a także wzrost koncentracji jonów $\mathrm{Ca}^{2+} \mathrm{i} \mathrm{OH}^{-}$. Po osiągnięciu pełnego nasycenia w roztworze wytrąca się $\mathrm{Ca}(\mathrm{OH})_{2}$; 
- wzrostu szybkości reakcji - następuje najbardziej gwałtowny etap hydratacji. $\mathrm{Ca}(\mathrm{OH})_{2}$ zaczyna krystalizować $\mathrm{z}$ roztworu i C-S-H odkłada się na przestrzeniach wypełnionych wodą. Hydraty rozrastają się, tworząc całość strukturalną przyszłego kamienia cementowego;

- zmniejszenia szybkości reakcji - maleje porowatość ukła$\mathrm{du}$, transport jonów i wody przez siatkę żelu C-S-H ulegają spowolnieniu, a natężenie hydratacji spada;

- małej szybkości reakcji - proces hydratacji trwa dalej. Struktura ulega zagęszczeniu, zmniejsza się porowatość i następuje wzrost wytrzymałości na ściskanie. Ten etap może trwać bardzo długo.

Zaczyn cementowy tuż po wtłoczeniu do przestrzeni pierścieniowej działa jak płyn i utrzymuje stałe ciśnienie hydrostatyczne działające na złoże, równoważąc ciśnienie złożowe. Następnie zachodzi proces żelowania zaczynu cementowego, tzn. budowanie statycznej wytrzymałości strukturalnej (SGS), aż do całkowitego związania cementu. Proces żelowania ogranicza zdolność zaczynu cementowego do utrzymywania ciśnienia hydrostatycznego wyższego niż ciśnienie złożowe, co może prowadzić do wtargnięcia gazu do przestrzeni pierścieniowej i jego penetracji przez zaczyn. Przeprowadzone na świecie badania laboratoryjne wykazują, że wartość SGS około 500 funtów/100 stóp ${ }^{2}$, czyli około 250 Pa może zablokować przepływ gazu przez wiążący zaczyn - jest to tzw. wartość graniczna SGS. Relację między SGS a maksymalnym spodziewanym ciśnieniem oporu przepływu wyraża wzór (1) (Crook i Heathman, 1998; Radecki i Witek, 2000; Bybee, 2005; Mohammadi i Moghadasi, 2007):

$$
P_{\max }=\frac{S G S}{300} \cdot \frac{L}{D}
$$

gdzie:

$P_{\max }-$ maksymalne spodziewane ciśnienie oporu przepływu [psi],

$S G S$ - statyczna wytrzymałość strukturalna

[funty/100 stóp ${ }^{2}$,

300 - współczynnik przeliczeniowy dla $P_{\max }$ [psi],

$L$ - długość kolumny zaczynu cementowego [stopy],

$D$ - efektywna średnica kolumny zaczynu cementowego

(średnica otworu minus średnica rur okładzinowych) [cale].

Ciśnienie hydrostatyczne wywierane przez słup zaczynu cementowego obniża się wraz ze wzrostem SGS. Jak wspominano wcześniej, gdy ciśnienie hydrostatyczne spadnie poniżej ciśnienia złożowego, zanim zaczyn osiągnie odpowiednią wartość SGS, to najprawdopodobniej gaz rozpocznie przechodzenie przez niezwiązany do końca zaczyn cementowy, tworząc stałe kanały, które mogą być drogami jego niekontrolowanej migracji na powierzchnię (Rzepka i Stryczek, 2008).
W procesie żelowania zaczynu wyróżnia się ważny parametr, jakim jest tzw. czas przejścia (TT, ang. transition time). Jest on określany w literaturze (Rogers et al., 2004; Mohammadi i Moghadasi, 2007) jako czas między rozpoczęciem budowy SGS a osiągnięciem wartości granicznej SGS (tj. od wartości 50 Pa do wartości 250 Pa, czyli od około 100 funtów/100 stóp ${ }^{2}$ do 500 funtów/100 stóp²). Opóźnienie czasu początku budowy statycznej wytrzymałości strukturalnej pozwala na wydłużenie okresu, w którym przenoszone jest ciśnienie hydrostatyczne na złoże. Z kolei zastosowanie receptur o krótkim czasie przejścia TT, nieprzekraczającym 30-40 min, jest pomocne w planowaniu działań mających na celu ograniczenie migracji gazu z przestrzeni pierścieniowej, zwłaszcza w przypadku płytkiego otworu wiertniczego.

Rysunek 1 przedstawia schematycznie zmiany temperatury i ciśnień podczas wiązania zaczynu cementowego w otworze. Uzyskanie krótkiego okresu oznaczonego na wykresie jako CHP wpływa na ograniczenie wystąpienia ewentualnej ekshalacji gazu przez wiążący zaczyn cementowy.

Pomiar statycznej wytrzymałości strukturalnej można wykonywać, stosując np. urządzenie o nazwie Static Gel Strength
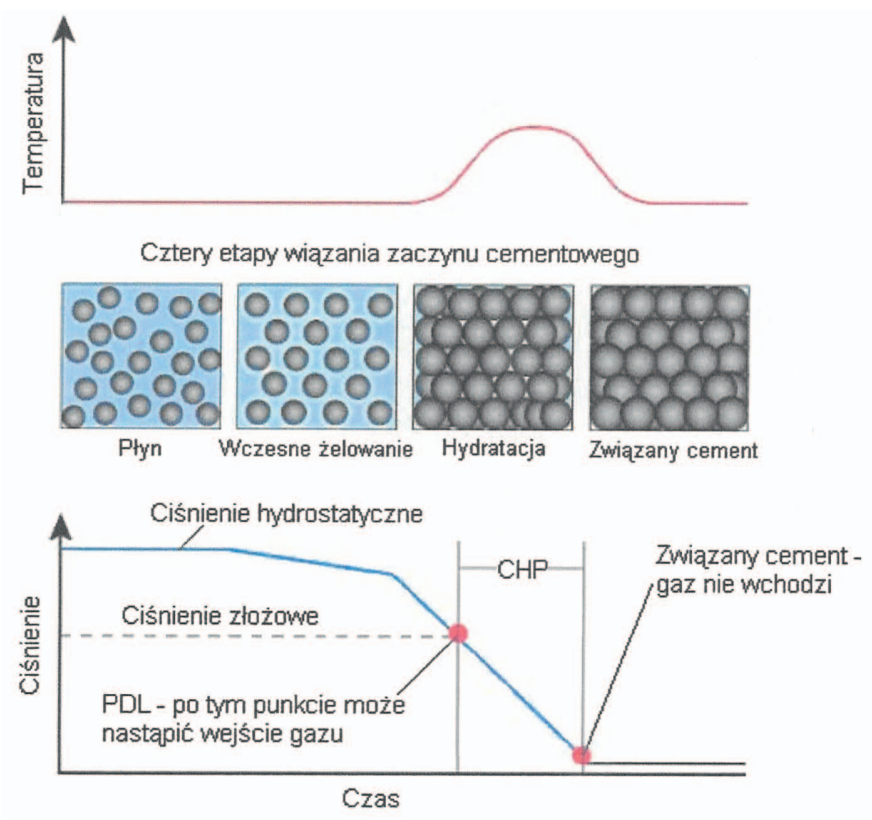

Rys. 1. Zmiany temperatury i ciśnień podczas wiązania zaczynu cementowego w otworze

Fig. 1. Temperature and pressure changes during bonding of cement slurry in the borehole

Measurement (SGSM). Aparat SGSM może symulować warunki otworowe (temperaturę i ciśnienie denne). Pomiar statycznej wytrzymałości strukturalnej prowadzony jest za pomocą mechanizmu wolno rotujących łopatek, wprawianych w ruch przez napęd magnetyczny. Metoda pomiaru zapewnia stałą i ciągłą rejestrację procesu żelowania zaczynu. Po zebraniu danych rysowana jest $\mathrm{w}$ programie komputerowym krzywa narastania 
statycznej wytrzymałości strukturalnej i obliczane są wartości czasów, przy których zaczyn osiąga m.in. 50 Pa i 250 Pa.

\section{Badania laboratoryjne zaczynów i kamieni cementowych}

Badania laboratoryjne mające na celu opracowanie składów zaczynów cementowych o krótkich czasach żelowania i wiązania do uszczelniania płytkich otworów wiertniczych były wykonywane w Zakładzie Technologii Wiercenia INiG - PIB zgodnie z normami: PN-EN ISO 10426-2 Przemyst naftowy i gazowniczy. Cementy $i$ materiały do cementowania otworów wiertniczych. Czesść 2: Badania cementów wiertniczych oraz PN-EN ISO 10426-6 Przemyst naftowy i gazowniczy. Cementy i materiaty do cementowania otworów. Część 6: Metody określania statycznej wytrzymałości strukturalnej zaczynów cementowych.

Ramowe składy zaczynów cementowych zamieszczono w tabelach 1a, 1b i 1c. Wszystkie zaczyny przeznaczone do uszczelniania płytkich otworów wiertniczych testowano w temperaturze $30^{\circ} \mathrm{C}$. Zaczyny zawierały $3 \% \mathrm{KCl}$ i były sporządzane na bazie cementu portlandzkiego CEM I 42,5 lub cementu wiertniczego klasy G.

Receptury w tabeli 1a, oznaczone symbolami A, B, C, D, E oraz F, posiadały w swym składzie dodatki: odpieniające, antyfiltracyjne, spęczniające, upłynniające i mikrocement. Różniły się między sobą rodzajem użytego lateksu wiertniczego oraz wykorzystanymi ilościami przyspieszacza wiązania. W składach A i B zastosowano lateks krajowy L1 (składy sporządzano na bazie cementu CEM I 42,5). Receptury C i D zawierały w swym składzie lateks zagraniczny L2 (jako spoiwo wiążące wykorzystano cement wiertniczy klasy G). Zaczyny o symbolach E i F sporządzano na bazie mikrolateksu L3 (spoiwem wiążącym był również cement wiertniczy klasy G).

Zaczyny zamieszczone w tabeli $1 \mathrm{~b}$ oznaczono symbolami H, J, K, L, M oraz N. W recepturach (podobnie jak w poprzednich zaczynach) używano dodatków odpieniających, antyfiltracyjnych, spęczniających, upłynniających, a także mikrocementu. We wszystkich składach stosowano cement portlandzki CEM I 42,5. Do zaczynów o symbolach H i J wprowadzano (jako przyspieszacz wiązania) szkło wodne potasowe (S1) w ilościach 2\% i 4\%. Przyspieszanie wiązania zaczynów oznaczonych symbolami K i L następowało przy użyciu szkła wodnego sodowego (S2), również w ilościach 2\% i 4\%. W zaczynach o symbolach $\mathrm{M}$ i $\mathrm{N}$ wykorzystano krzemionkę bezpostaciową (CB) w ilościach odpowiednio 2,5\% i 5\%.

W zaczynach $\mathrm{P}, \mathrm{R}, \mathrm{S}$ oraz T zastosowano nanokomponenty NS i NA w ilości $1 \%$ (tj. n- $\mathrm{SiO}_{2}$ oraz $\mathrm{n}-\mathrm{Al}_{2} \mathrm{O}_{3}$ ) natomiast w zaczynach U i W - polimer wielkocząsteczkowy w ilości 7\% (GS).
Dla wszystkich zaczynów cementowych wykonywano oznaczenia gęstości, a także pomiary narastania statycznej wytrzymałości strukturalnej (SGS), a co się z tym wiąże - czasu przejścia TT. Dodatkowo prowadzono badania początku i końca wiązania zaczynów za pomocą sześciokomorowego automatycznego aparatu Vicata.

Wyniki badań zaczynów cementowych zamieszczono w tabeli 2. Gęstości badanych zaczynów wahały się w granicach $1800-1840 \mathrm{~kg} / \mathrm{m}^{3}$.

Zaczyny cementowe na bazie lateksu wiertniczego L1 (składy A i B) uzyskały czas przejścia TT od 25 min do 40 min (w zależności od ilości zastosowanego przyspieszacza wiązania), a ich czas początku wiązania wynosił od około $200 \mathrm{~min}$ do 285 min. W recepturach o symbolach C, D, E oraz F na bazie lateksów L2 oraz L3 zaobserwowano wyraźnie dłuższe czasy TT (z przedziału od $65 \mathrm{~min}$ do $100 \mathrm{~min}$ ). Czasy początku wiązania zaczynów $\mathrm{C}, \mathrm{D}, \mathrm{E}$ oraz $\mathrm{F}$ również uległy wydłużeniu w porównaniu do zaczynów A i B.

Receptury H, J, K, L, z dodatkiem różnych rodzajów i ilości szkła wodnego (S1 i S2), uzyskały czasy przejścia TT od około $1 / 2$ godz. do około 11/2 godz. Czas TT można było regulować za pomocą ilości dodawanego szkła wodnego. Użycie 4\% zarówno szkła wodnego sodowego, jak i szkła wodnego potasowego spowodowało skrócenie czasu przejścia TT do wartości około 30 min. Czasy początku wiązania zaczynów z dodatkiem szkła wodnego były dłuższe niż te uzyskane dla zaczynów lateksowych. W zaczynach oznaczonych symbolami M i N, zawierających krzemionkę bezpostaciową (CB) w różnych ilościach, uzyskano czasy przejścia TT wynoszące odpowiednio $50 \mathrm{~min}$ i 59 min. Czasy początku wiązania zaczynów były zbliżone do tych, jakie uzyskano w przypadku zaczynów lateksowych.

Użycie n- $\mathrm{SiO}_{2}$ w składach o symbolach $\mathrm{P}$ i R spowodowało, że zaczyny te dość szybko żelowały (czas TT dla składu P wynosił $34 \mathrm{~min}$, a dla składu $\mathrm{R}$ był równy $27 \mathrm{~min}$ ). Początki wiązania receptury uzyskały odpowiednio po 265 min i $245 \mathrm{~min}$. Najszybsze żelowanie spośród wszystkich zbadanych próbek otrzymano dla zaczynów zawierających n- $\mathrm{Al}_{2} \mathrm{O}_{3}$ (tj. próbek o symbolach S i T). Zaczyn S, niezawierający w ogóle przyspieszacza wiązania, uzyskał czas przejścia wynoszący $22 \mathrm{~min}$, a zaczyn T, zawierający $2 \%$ dodatku przyspieszającego, cechował się czasem przejścia TT równym zaledwie $12 \mathrm{~min}$. Obydwie receptury $\mathrm{S}$ oraz $\mathrm{T}$ cechowały się również bardzo krótkimi czasami początku wiązania (odpowiednio $205 \mathrm{~min}$ i $120 \mathrm{~min}$ ). Ostatnie z testowanych składów, o symbolach $\mathrm{U}$ i W, zawierające polimer GS, również wykazywały tendencję do szybkiego żelowania. Receptura U, niezawierająca przyspieszacza wiązania, uzyskała czas przejścia TT wynoszący 36 min. Wprowadzenie 2\% przyspieszacza wiązania do receptury W spowodowało skrócenie czasu TT do 19 min. Zaczyny U i W osiągnęły początek wiązania odpowiednio po $375 \mathrm{~min}$ i $240 \mathrm{~min}$. 
Na rysunkach od 2 do 7 zamieszczono krzywe żelowania dla wybranych (reprezentatywnych) zaczynów cementowych. Przedstawiono krzywe żelowania zaczynów o symbolach B, S, T, U, W oraz H. Zielone linie pokazują przebieg narastania SGS. Na wykresach zamieszczono informacje o uzyskaniu przez zaczyny odpowiedniej wartości SGS oraz dane na temat ich czasów przejścia TT. Pięć pierwszych rysunków (dla zaczynu z lateksem L1 oraz zaczynów zawierających
NA i GS) obrazuje przebieg szybkiego żelowania (krótkich czasów przejścia TT). Zaczyny o takich krzywych żelowania mogą być z powodzeniem proponowane do zastosowania przemysłowego.

Ostatni rysunek (dla zaczynu z dodatkiem szkła wodnego S1) przedstawia wydłużone żelowanie (czas TT dochodzi do $1 \frac{1}{2}$ godz.). Taka receptura nie gwarantuje wytworzenia bariery blokującej ewentualny przepływ gazu.

Tabela 1a. Składy testowanych zaczynów cementowych

Table 1a. Compositions of tested cement slurries

\begin{tabular}{|l|c|c|c|c|c|c|}
\hline \multicolumn{1}{c|}{$\begin{array}{c}\text { Symbol zaczynu/ } \\
\text { Skladniki w \% bwoc* }\end{array}$} & Zaczyn A & Zaczyn B & Zaczyn C & Zaczyn D & Zaczyn E & Zaczyn F \\
\hline \hline Woda wodociągowa & 40 & 40 & 38 & 38 & 38 & 38 \\
\hline KCl $^{* *}$ & 3 & 3 & 3 & 3 & 3 & 3 \\
\hline Dodatek odpieniający & 0,5 & 0,5 & 0,5 & 0,5 & 0,5 & 0,5 \\
\hline Upłynniacz & 0,3 & 0,3 & 0,3 & 0,3 & 0,3 & 0,3 \\
\hline Dodatek antyfiltracyjny & 0,1 & 0,1 & 0,1 & 0,1 & 0,1 & 0,1 \\
\hline Stabilizator lateksu & 1 & 1 & 1 & 1 & 1 & 1 \\
\hline Lateksy wiertnicze & L1, L2 lub L3)** & $\mathbf{L 1}$ & $\mathbf{L 2}$ & $\mathbf{L 2}$ & $\mathbf{L 3}$ & $\mathbf{L 3}$ \\
\hline Dodatek spęczniający & 10 & 10 & 10 & 10 & 10 & 10 \\
\hline Przyspieszacz wiązania & 0,1 & 0,1 & 0,2 & 0,2 & 0,2 & 0,2 \\
\hline Mikrocement & 2 & 3 & 1 & 2 & 1 & 2 \\
\hline Cement portlandzki CEM I 42,5 & 10 & 10 & 10 & 10 & 10 & 10 \\
\hline Cement wiertniczy klasy G & - & - & 100 & 100 & 100 & 100 \\
\hline
\end{tabular}

${ }^{*}$ bwoc - tj. w stosunku do masy suchego cementu

** $\mathrm{KCl}$ dodawany był w stosunku do masy wody zarobowej (bwow).

*** Zastosowano lateks krajowy (L1 w składach A i B), lateks zagraniczny (L2 w składach C i D) oraz mikrolateks zagraniczny (L3 w składach E i F).

Tabela 1b. Składy testowanych zaczynów cementowych

Table 1b. Compositions of tested cement slurries

\begin{tabular}{|l|c|c|c|c|c|c|}
\hline \multicolumn{1}{c|}{$\begin{array}{c}\text { Symbol zaczynu/ } \\
\text { Składniki w \% bwoc }\end{array}$} & Zaczyn H & Zaczyn J & Zaczyn K & Zaczyn L & Zaczyn M & Zaczyn N \\
\hline \hline Woda wodociągowa & 45 & 45 & 45 & 45 & 52 & 52 \\
\hline KCl $^{* *}$ & 3 & 3 & 3 & 3 & 3 & 3 \\
\hline Dodatek odpieniający & 0,5 & 0,5 & 0,5 & 0,5 & 0,3 & 0,3 \\
\hline Upłynniacz & 0,2 & 0,2 & 0,2 & 0,2 & 0,2 & 0,2 \\
\hline Szkło wodne (S1 lub S2) lub & $\mathbf{S 1}$ & $\mathbf{S 1}$ & $\mathbf{S 2}$ & $\mathbf{S 2}$ & $\mathbf{C B}$ & $\mathbf{C B}$ \\
krzemionka bezpostaciowa (CB) & 2,0 & 4,0 & 2,0 & 4,0 & 2,5 & 5,0 \\
\hline Dodatek antyfiltracyjny & 0,2 & 0,2 & 0,2 & 0,2 & 0,2 & 0,2 \\
\hline Lateks krajowy (L1) & 10 & 10 & 10 & 10 & 10 & 10 \\
\hline Dodatek spęczniający & 0,3 & 0,3 & 0,3 & 0,3 & 0,3 & 0,3 \\
\hline Mikrocement & 10 & 10 & 10 & 10 & 20 & 20 \\
\hline Cement portlandzki CEM I 42,5 & 100 & 100 & 100 & 100 & 100 & 100 \\
\hline
\end{tabular}

${ }^{*}$ bwoc - tj. w stosunku do masy suchego cementu

** $\mathrm{KCl}$ dodawany był w stosunku do masy wody zarobowej (bwow).

*** Zastosowano szkło wodne potasowe (S1 w składach H i J), szkło wodne sodowe (S2 w składach K i L) oraz krzemionkę bezpostaciową (CB w składach $\mathrm{M}$ i N). 
Tabela 1c. Składy testowanych zaczynów cementowych

Table 1c. Compositions of tested cement slurries

\begin{tabular}{|l|c|c|c|c|c|c|}
\hline \multicolumn{1}{|c|}{$\begin{array}{c}\text { Symbol zaczynu/ } \\
\text { Skladniki w \% bwoc* }\end{array}$} & Zaczyn P & Zaczyn R & Zaczyn S & Zaczyn T & Zaczyn U & Zaczyn W \\
\hline \hline Woda wodociągowa & 46 & 46 & 52 & 52 & 50 & 50 \\
\hline KCl** $^{* *}$ & 3 & 3 & 3 & 3 & 3 & 3 \\
\hline Nanokomponenty (NS lub NA) lub po- & NS & NS & NA & NA & GS & GS \\
limer wielkocząsteczkowy (GS) & 1,0 & 1,0 & 1,0 & 1,0 & 7,0 & 7,0 \\
\hline Dodatek odpieniający & 0,3 & 0,3 & 0,3 & 0,3 & 0,3 & 0,3 \\
\hline Upłynniacz & 0,4 & 0,4 & 0,1 & 0,1 & 0,2 & 0,2 \\
\hline Dodatek antyfiltracyjny & - & - & - & - & 0,1 & 0,1 \\
\hline Przyspieszacz wiązania & 2 & 3 & - & 2 & - & 2 \\
\hline Mikrocement & - & - & 5,0 & 5,0 & 5,0 & 5,0 \\
\hline Cement portlandzki CEM I 42,5 & - & - & 100 & 100 & 100 & 100 \\
\hline Cement wiertniczy klasy G & 100 & 100 & - & - & - & - \\
\hline
\end{tabular}

* bwoc - tj. w stosunku do masy suchego cementu

${ }^{* *} \mathrm{KCl}$ dodawany był $\mathrm{w}$ stosunku do masy wody zarobowej (bwow).

*** Zastosowano n- $\mathrm{SiO}_{2}$ (NS w składach P i R), n- $\mathrm{Al}_{2} \mathrm{O}_{3}$ (NA w składach $\mathrm{S}$ i T) oraz polimer wielkocząsteczkowy (GS w składach U i W).

Tabela 2. Parametry zaczynów i kamieni cementowych testowanych w temperaturze $30^{\circ} \mathrm{C}$

Table 2. Parameters of cement slurries and stones tested at $30^{\circ} \mathrm{C}$

\begin{tabular}{|c|c|c|c|c|c|c|}
\hline $\begin{array}{c}\text { Oznaczany } \\
\text { parametr/ } \\
\text { Symbol zaczynu }\end{array}$ & $\begin{array}{c}\text { Gęstość zaczynu } \\
\text { cementowego } \\
{\left[\mathrm{kg} / \mathrm{m}^{3}\right]}\end{array}$ & $\begin{array}{c}\text { Czas, po którym } \\
\text { zaczyn uzyskał } \\
\text { SGS wynoszącą } \\
50 \mathrm{~Pa} \text { [minuty] }\end{array}$ & $\begin{array}{l}\text { Czas, po którym } \\
\text { zaczyn uzyskał } \\
\text { SGS wynoszącą } \\
250 \mathrm{~Pa} \text { [minuty] }\end{array}$ & $\begin{array}{c}\text { Czas przejścia } \\
\text { TT } \\
\text { [minuty }]\end{array}$ & $\begin{array}{c}\text { Początek } \\
\text { wiązania zaczynu } \\
\text { [minuty] }\end{array}$ & $\begin{array}{c}\text { Koniec } \\
\text { wiązania zaczynu } \\
{[\text { minuty }]}\end{array}$ \\
\hline Zaczyn A & 1840 & 3 & 43 & 40 & 285 & 370 \\
\hline Zaczyn B & 1840 & 16 & 41 & 25 & 200 & 375 \\
\hline Zaczyn C & 1800 & 10 & 91 & 81 & 355 & 405 \\
\hline Zaczyn D & 1800 & 25 & 90 & 65 & 320 & 385 \\
\hline Zaczyn E & 1800 & 18 & 118 & 100 & 380 & 490 \\
\hline Zaczyn F & 1800 & 52 & 134 & 82 & 340 & 465 \\
\hline Zaczyn H & 1820 & 26 & 113 & 87 & 540 & 1030 \\
\hline Zaczyn J & 1820 & 16 & 47 & 31 & 520 & 960 \\
\hline Zaczyn K & 1820 & 31 & 82 & 51 & 560 & 780 \\
\hline Zaczyn L & 1820 & 23 & 54 & 31 & 500 & 740 \\
\hline Zaczyn M & 1800 & 24 & 83 & 59 & 450 & 540 \\
\hline Zaczyn N & 1800 & 17 & 67 & 50 & 370 & 490 \\
\hline Zaczyn P & 1830 & 20 & 54 & 34 & 265 & 375 \\
\hline Zaczyn R & 1830 & 6 & 33 & 27 & 245 & 395 \\
\hline Zaczyn S & 1810 & 13 & 35 & 22 & 205 & 250 \\
\hline Zaczyn T & 1810 & 5 & 17 & 12 & 120 & 175 \\
\hline Zaczyn U & 1820 & 21 & 57 & 36 & 375 & 560 \\
\hline Zaczyn W & 1820 & 34 & 53 & 19 & 240 & 290 \\
\hline
\end{tabular}

\section{Podsumowanie}

Po wykonaniu szeregu badań i analiz płynnych zaczynów cementowych można sformułować następujące wnioski:

1) W celu przeciwdziałania migracji gazu w otworze wiertniczym z płytkich horyzontów gazowych należy m.in. zastosować zaczyn cementowy o szybkim żelowaniu (maksymalnie około 30-40 min) i odpowiednio dobranym do warunków otworowych czasie wiązania. Pozwoli to na wytworzenie szczelnej bariery uniemożliwiającej przedostawanie się gazu na powierzchnię przez przestrzeń pierścieniową otworu wiertniczego.

2) Odpowiednio zmodyfikowane (za pomocą lateksu, nanokomponentów czy polimeru wielkocząsteczkowego) zaczyny 


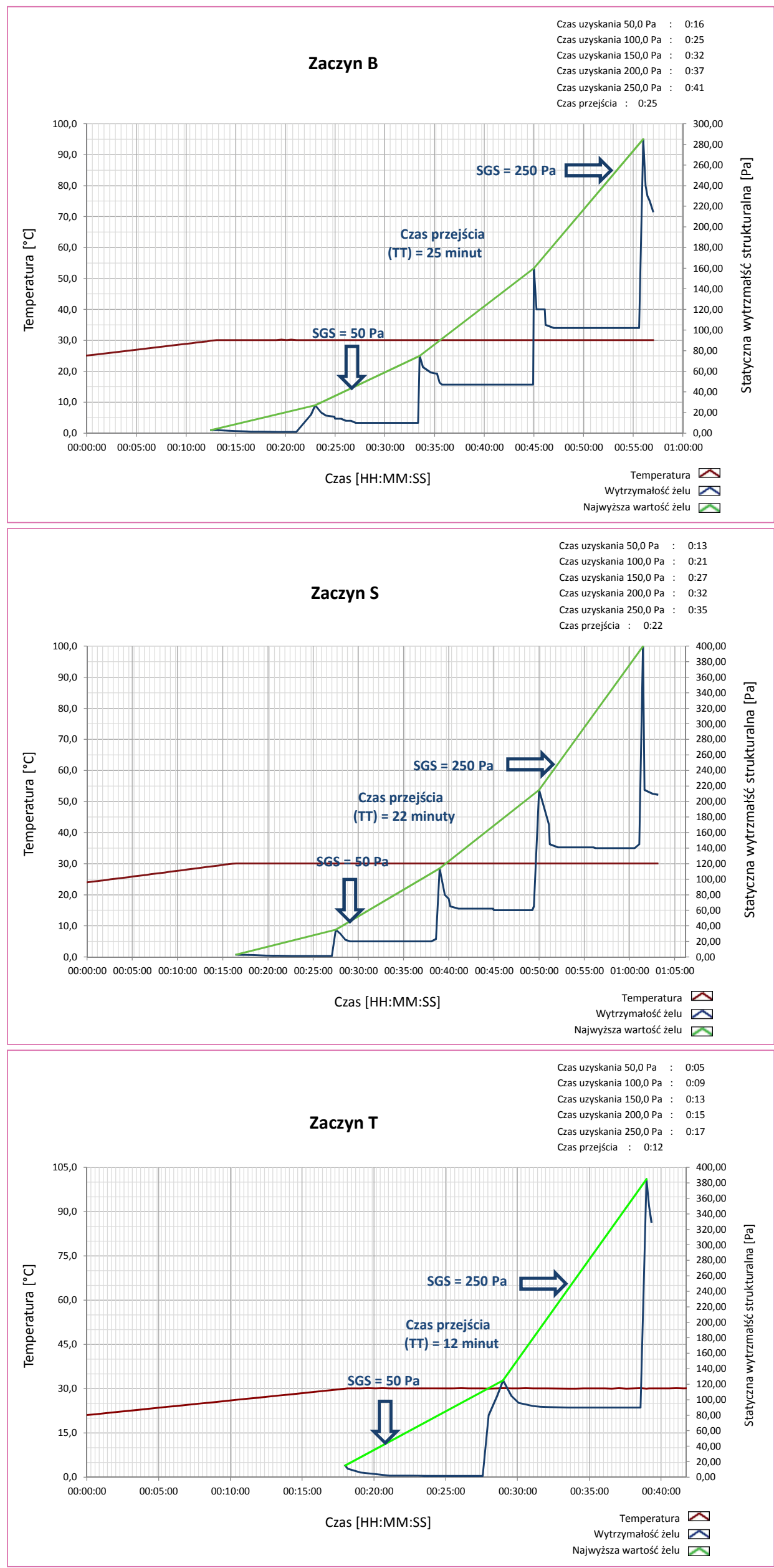

Rys. 2. Narastanie statycznej wytrzymałości strukturalnej zaczynu cementowego o symbolu B

Fig. 2. Static gel strength development for cement slurry B

Rys. 3. Narastanie statycznej wytrzymałości strukturalnej zaczynu cementowego o symbolu S

Fig. 3. Static gel strength development for cement slurry $\mathrm{S}$

Rys. 4. Narastanie statycznej wytrzymałości strukturalnej zaczynu cementowego o symbolu $\mathrm{T}$

Fig. 4. Static gel strength development for cement slurry $\mathrm{T}$ 


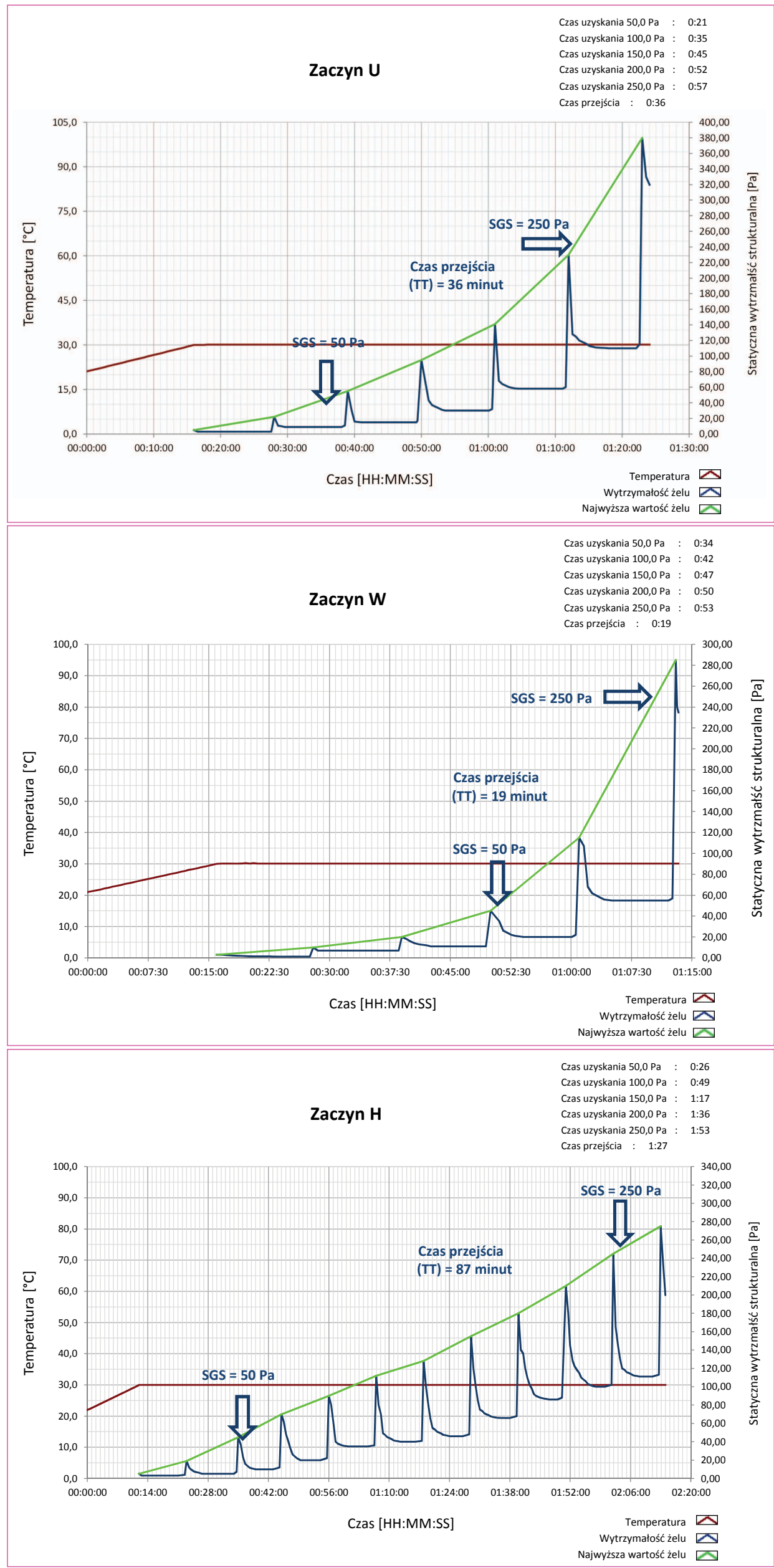

Rys. 5. Narastanie statycznej wytrzymałości strukturalnej zaczynu cementowego o symbolu U

Fig. 5. Static gel strength development for cement slurry $\mathrm{U}$

Rys. 6. Narastanie statycznej wytrzymałości strukturalnej zaczynu cementowego o symbolu W

Fig. 6. Static gel strength development for cement slurry $\mathrm{W}$

Rys. 7. Narastanie statycznej wytrzymałości strukturalnej zaczynu cementowego o symbolu $\mathrm{H}$

Fig. 7. Static gel strength development for cement slurry $\mathrm{H}$ 
cementowe na bazie cementu portlandzkiego CEM I 42,5 lub cementu wiertniczego klasy $\mathrm{G}$ z powodzeniem nadają się do uszczelniania rur okładzinowych na odcinkach występowania płytko zalegających poziomów gazonośnych o podwyższonym ryzyku wystąpienia migracji gazu.

3) Receptury zaczynów zamieszczone w artykule posiadają odpowiednie parametry technologiczne. Niektóre z zaczynów, te o nieco dłuższym czasie przejścia (TT, ang. transition time) oraz dłuższym czasie początku wiązania, mogą być zastosowane do uszczelniania głębszych interwałów. Inne (o bardzo krótkich czasach TT) sprawdzą się lepiej przy cementowaniu początkowego interwału otworu (np. od 0 do około $150 \mathrm{~m}$ ).

4) Wyjątkowo korzystne parametry technologiczne uzyskano dla zaczynów cementowych o gęstościach około 1800$1840 \mathrm{~kg} / \mathrm{m}^{3}$ zawierających lateks krajowy L1, nanotlenek glinu NA czy polimer wielkocząsteczkowy GS. Zarówno próbki zawierające $10 \%$ lateksu, jak i te zawierające $1 \%$ $\mathrm{n}-\mathrm{Al}_{2} \mathrm{O}_{3}$ oraz $7 \%$ polimeru GS cechowały się odpowiednim przebiegiem krzywej żelowania (narastania statycznej wytrzymałości strukturalnej). Ich czasy przejść TT wynosiły od kilkunastu do kilkudziesięciu minut (co świadczy o ich wysokiej zdolności do zapobiegania migracji gazu z płytkich horyzontów gazowych).

5) Czasy wiązania badanych zaczynów można z powodzeniem regulować za pomocą powszechnie używanych w przemyśle środków przyspieszających. Testowane na aparacie Vicata zaczyny (proponowane do użycia przemysłowego) posiadały czasy początku wiązania w przedziale od 120 min do około 300 min. Powoduje to, że w zależności od przewidywanej długości zabiegu cementowania można z powodzeniem dobrać odpowiedni czas wiązania zaczynu do określonych warunków technologicznych.

6) Zaczyny cementowe o symbolach B, P, R, S, T, U oraz W (lub zaczyny o zbliżonych do nich składach) z uwagi na ich bardzo dobre parametry technologiczne mogą znaleźć zastosowanie w procesie cementowania kolumn rur okładzinowych.

Artykuł powstał na podstawie projektu pt. Multilateralny matośrednicowy otwór odgazowujący pokłady węgla-MINE GAS SLIMHOLE DRILLING MIGASLIDRILL - praca INiG - PIB na zlecenie NCBiR oraz PGNiG; nr zlecenia: 6037/KW/2020, nr archiwalny: DK-0601/0005/2019.

\section{Literatura}

ASTM International, 2010. Standard Test Method for Time of Setting of Hydraulic Cement by Vicat Needle: $<$ http://share.its.ac.id/pluginfile. php/19645/mod_folder/content/0/CON013_C191.pdf> (dostęp: 02.02.2018).

Bybee K., 2005. Transition Time of Cement Slurries. J. Pet. Technol., 57(8): 45-70. DOI: 10.2118/0805-0045-JPT.

Crook R., Heathman J., 1998. Predicting potential gas-flow rates to help determine the best cementing practices. Drilling Contractor, November-December: 40-43.

Dębińska E., 2013. Wyznaczanie statycznej wytrzymałości strukturalnej i wczesnej wytrzymałości mechanicznej zaczynów cementowych. Nafta-Gaz, 2: 134-142.

Kurdowski W., 2010. Chemia cementu i betonu. Wydawnictwo Naukowe PWN/Polski Cement, Warszawa.

Kurdowski W., 2014. Cement and concrete chemistry. Springer Science \& Business, New York.

Mohammadi M., Moghadasi J., 2007. New cement formulation that solves gas migration problems in Iranian South Pars Field condition. SPE Middle East Oil and Gas Show and Conference, Manama, Bahrain. DOI: 10.2118/105663-MS.

Neville A.M., 2000. Właściwości betonu. Wydawnictwo Polski Cement, Kraków.

Radecki S., Witek W., 2000. Dobór technik i technologii cementowania w aspekcie występowania migracji gazu. Nafta-Gaz, 9: 487-497.

Ridi F., 2010. Hydration of Cement: Still a Lot to Be Understood. Dipartimento di Chimica \& CSGI Università di Firenze, La Chimica L'Industria, 3: 110-117.

Rogers M.J., Dillenbeck R.L., Eid R.N., 2004. Transition Time of Cement Slurries, Definitions and Misconceptions, Related to Annular Fluid Migration. Society of Petroleum Engineers. DOI: 10.2118/90829-MS.

Rzepka M., Kędzierski M., 2019. Zaczyny cementowe z dodatkiem nanokomponentów do uszczelniania kolumn rur okładzinowych w otworach wiertniczych o głębokości końcowej około 1000-2000 metrów. Nafta-Gaz, 11: 674-682. DOI: 10.18668/NG.2019.11.02.

Rzepka M., Kędzierski M., 2020. Możliwości zastosowania nanotlenku glinu w zaczynach cementowych przeznaczonych do uszczelniania rur okładzinowych w otworach wiertniczych. Nafta-Gaz, 1: 46-56. DOI: 10.18668/NG.2020.01.06.

Rzepka M., Stryczek S., 2008. Laboratoryjne metody określania parametrów technologicznych świeżych zaczynów uszczelniających przed zabiegiem związanym z procesem uszczelniania kolumn rur okładzinowych w otworach wiertniczych. Wiertnictwo, Nafta, Gaz, 25(2): 625-636.

Scott S.J., Adel A.A., Abdullah S.A., 2003. Gas migration after cementing greatly reduced. Society of Petroleum Engineers. DOI: 10.2118/81414-MS

Stryczek S., Gonet A., 2001. Wymagania odnośnie zaczynów uszczelniających stosowanych w technologiach wiertniczych. Sympozjum Naukowo-Techniczne ,Cementy w budownictwie, robotach wiertniczych i inżynieryjnych oraz hydrotechnice”, Piła-Płotki 23.05.2001. Materiaty konferencyjne: 31-41.

Velayati A., Kazemzadeh E., Soltanian H., Tokhmechi B., 2015. Gas migration through cement slurries analysis: A comparative laboratory study. Int. J. Min. \& Geo-Eng., 49(2): 281-288. DOI: 10.22059/ijmge.2015.56113.

\section{Akty prawne i dokumenty normatywne}

PN-EN ISO 10426-2 Przemysł naftowy i gazowniczy. Cementy i materiały do cementowania otworów. Część 2: Badania cementów wiertniczych.

PN-EN ISO 10426-6 Przemysł naftowy i gazowniczy. Cementy i materiały do cementowania otworów. Część 6: Metody określania statycznej wytrzymałości strukturalnej zaczynów cementowych.

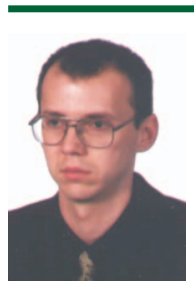

Dr inż. Marcin RZEPKA

Kierownik Laboratorium Zaczynów Uszczelniających w Zakładzie Technologii Wiercenia

Instytut Nafty i Gazu - Państwowy Instytut Badawczy ul. Lubicz 25 A

31-503 Kraków

E-mail: marcin.rzepka@inig.pl

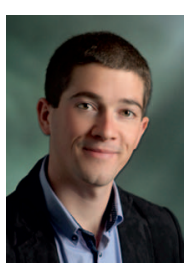

Mgr inż. Miłosz KĘDZIERSKI

Asystent w Zakładzie Technologii Wiercenia

Instytut Nafty i Gazu - Państwowy Instytut Badawczy

ul. Lubicz $25 \mathrm{~A}$

31-503 Kraków

E-mail: milosz.kedzierski@inig.pl 